\title{
KEGIATAN PELATIHAN KETERAMPILAN TANGAN UNTUK MENINGKATKAN KREATIVITAS IBU-IBU WARGA PERUMAHAN ANGGARA GRAHA RW 12, BATAM
}

\section{HANDYCRAFT TRAINING PROGRAM ON IMPROVING HOUSEWIVES' CREATIVENESS AT ANGGARA GRAHA RW 12, BATAM}

\author{
Rahmi \\ Prodi Pendidikan Biologi, Fakultas Keguruan dan Ilmu Pendidikan, \\ Universitas Riau Kepulauan, Batam, Indonesia \\ rahmikumbang@gmail.com
}

\begin{abstract}
Abstrak
Pelaksanaan program pelatihan kerajinan tangan pada pengabdian ini didasarkan pandangan ibu-ibu warga kelurahan sagulung kota di RW.12 memerlukan inovasi baru dalam hal kerajinan tangan karena masih terbatasnya ide-ide kreatif dari ibu-ibu di sana, hal ini juga dikarenakan kurangnya informasi terbaru yang didapat oleh ibu-ibu dari media cetak dan sosmed. Tujuan pelaksanaan program ini adalah : (a) meningkatkan kreatifitas dan keterampilan ibu-ibu tentang penggunaan kerajinan tangan dari stik es krim yang nantinya dapat dibuat frame (bingkai foto), kotak pensil di meja belajar, dan asbak rokok, (b) melatih dan mendampingi ibu-ibu tentang penggunaan dan cara membuat kerajinan tangan tersebut. Metode pelaksanaan kegiatan meliputi tiga tahap, yaitu : perencanaan, tindakan dan evaluasi. Hasil pelaksanaan program adalah (a) adanya peningkatan kreatifitas dan keterampilan ibu-ibu tentang penggunaan kerajinan dari bahan stik es krim dalam kategori baik, (b) hasil kerajinan tangan dalam penggunaan stik es krim berkualitas baik.
\end{abstract}

Kata Kunci : Kerajinan Tangan, Stik Es Krim

\begin{abstract}
This handycraft training program was conducted as community services based on housewives communities' needs at Kelurahan Sagulung Kota $R W 12$ in order to know new innovation on handycraft, it was due to their limited creative ideas. it was caused by the lackness of getting new information from mass media or social media. The aims of this program were to: (a) improve the housewives comunities' creativities and skills on using ice cream stick become a frame, pencil box on study table, and cigarette ashtray. (b) give training and assitance housewives comunity how to use and make those new handycraft. The program method consisted three steps, they were: planning, action, and evaluation. The final result of this program were: (a) there was a significant housewives comunities' creativity and skills improvment on using and making handycraft made from the ice cream stick, (b) the result of the handycraft made from the ice cream stick could be categorized on good quality.
\end{abstract}

Key words: Handycraft and Ice Cream Stick

\section{PENDAHULUAN}

Kerajinan tangan itu sendiri adalah hal yang berkaitan dengan buatan tangan atau kegiatan yang berkaitan dengan barang yang dihasilkan melalui keterampilan tangan (kerajinan tangan), kerajinan yang dibuat biasanya terbuat dari berbagai bahan. Dari 
kerajinan ini menghasilkan hiasan atau benda seni maupun barang pakai. (http://id.wikipedia.org/wiki/kerajinan).

Arti lain dari kerajinan adalah suatu usaha yang dilakukan secara terus menerus dengan penuh semangat ketekunan, kecekatan, kegigihan, dan berdaya maju yang luas dalam melakukan suatu karya. Dengan kata lain kerajinan merupakan hasil usaha yang dilakukan secara sadar dan terampil untuk menghasilkan sebuah produk baru yang memiliki nilai manfaat. (http://id. Wikipedia.org/wiki/kerajinan)

Menurut sudita ketut kerajinan tangan merupakan Terkait dengan istilah kerajian, Couto (2000:17) menyatakan bahwa kerajinan berhubungan dengan sifat rajin dari tangan atau keterampilan dengan sifat dari tangan atau keterampilan. Kerajinan berasal dari kata “ craft"dan handicraft (inggris) yang berarti “ keahlian “. Seni kerajinan juga lebih banyak dibuat sebagai benda pakai. Bentuk seni kerajinan ada bermacam-macam, seperti : kerajinan kertas, kerajinan bambu, kerajinan tangan, kerajinankeramik, dan kerajinan kulit.

Sampah merupakan bahan-bahan sisa atau bekas aktivitas manusia. Sampah yang ada di masyrakat dapat berupa sampah kering, basah, maupun B3. Adanya sampah dalam jumlah melimpah mencemari lingkungan baik mencemari tanah maupun air. Lingkungan yang tercemar menjadi kotor, kumuh serta bau. Untuk mengurangi dampak yang timbul dari adanya sampah yaitu dengan melakukan 3R ( reuse, reduce dan recyle) atau daur ulang merupakan upaya mengubah barang bekas atau sudah tidak terpakai lagi menjadi barang yang bisa dimanfaatkan kembali. ( tesa yulia, 2017)

Ibu RW di kelurahan sagulung kota merupakan seorang yang kreatif dan inovatif. Beliau selalau memberikan ide-ide baru dalam membuat sebuah kerajinan tangan dari bahanbahan bekas atau yang sudah tidak terpakai lagi. Beliau juga aktif dalam kegiatan ibu-ibu PKK,. Sudah banyak kerajinan yang sudah beliau dan ibu-ibu disekitar lingkungan tersebut hasilkan, bahkan ada yang membeli kerajinan dari ibu-ibu di kelurahan sagulung kota.

Informasi yang cukup menarik dari ibu-ibu kelurahan sagulung kota di RT 1 dan RT 3 untuk kerajinan ibu-ibu di sana udah lama aktif dalam pembuatan kerajinan tangan. Hanya saja biasanya ibu-ibu disana memanfaatkan ban bekas untuk dibuat tempat sampah, kursi. Ada juga dari kantong asoi/ kresek dibuat bunga. Namun, ibu-ibu disana sering mengalami kesulitan disaat membuat kerajinan baru dari bahan bekas yang lain. Hal ini disebabkan juga karena kurangnya informasi yang didapat ibu-ibu kelurahan sagulung kota sehingga tidak ada inovasi keterampilan yang baru mengenai bahan keterampilan yang lain. Ibu-ibu di sagulung kota juga terbiasa membuat kerajinan yang sudah mereka terbiasa buat. 
Melihat dari permasalahan yang ada di lapangan kelurahan sagulung kota di RT.01 dan RT.03 RW 12 yang memerlukan inovasi baru dalam hal kerajinan tangan karena masih terbatasnya ide-ide kreatif dari ibu-ibu di sana. Maka dosen bersama dengan mahasiswa sebagai tim pelaksana memandang perlu untuk mengadakan kegiatan pelatihan kerajinan tangan sebagai tambahan ide atau masukkan untuk ibu-ibu kelurahan sagulung kota.

Adapun kerajinan tangan yang akan dibuat dari tim pelaksana berikan pada ibu-ibu kelurahan sagulung kota adalah kerajinan tangan yang berasal dari "stik es krim". Dengan menggunakan bahan dari stik es krim ini ibu-ibu kelurahan sagulung kota dapat membuat kerajinan tangan dalam bentuk yang leibh inovatif dan kreatif contohnya adalah : dapat membuat frame ( bingkai foto), kotak pensil yang bisa ditaruh di atas meja, asbak rokok. Diharapkan dengan menggunakan bahan dari stik es krim ini ibu-ibu kelurahan sagulung kota lebih rajin dan bersemangat dalam membuat kerajinan tangan.

\section{METODOLOGI}

Program ini dilaksanakan dalam tiga tahap, perencanaan, pelaksanaan dan evaluasi. . kegiatan-kegiatan dalam tahap-tahapan sebagai berikut:

\section{Perencanaan}

Pada kegiatan perencanaan tim pelaksana mengundang mitra untuk dijelaskan maksud, tujuan dan teknis pelaksanaan kegiatan pelatihan, sosialisasi program pada mitra , dan penyusunan program pelatihan.

\section{Tindakan}

Tindakan dalam kegiatan ini berupa implementasi program. Kegiatan-kegiatan yang dilakukan adalah (a) meningkatkan kreatifitas dan keterampilan ibu-ibu tentang penggunaan dan cara membuat bahan kerajinan dari stik es krim. (b) melatih ibu-ibu tentang penggunaan bahan dari stik es krim (c) melatih, mendampingi, dan mempraktekkan secara langsung pembuatan kerajinan dari bahan stik es krim .

\section{Evaluasi}

Evaluasi dalam kegiatan ini diperlukan untuk mengetahui sejauh mana pemberian pelatihan yang dilakukan tim pelaksana dipahami dan bisa diaplikasikan langsung oleh ibuibu kelurahan sagulung kota. Contoh untuk pelatihan kerajinan dengan stik es krim dengan cara memberikan kesempatan langsung kepada ibu-ibu untuk membuat bentuk yang baru. Disana akan terlihat sejauh mana kreatifitas ibu-ibu dalam membuat model kerajinan yang berbeda. 


\section{PEMBAHASAN}

\section{Hasil pelaksanaan kegiatan pelatihan}

a. Kegiatan pelatihan kerajinan tangan dari bahan stik es krim dilaksanakan pada hari Minggu, tanggal 20 dan 27 Agustus 2017. Kegiatan pengabdian dihadiri oleh 15 orang peserta dan peserta menunjukkan antusiasme cukup besar terhadap program pengabdian.

b. Cara membuat pelatihan kerajinan tangan dapat semuanya disampaikan oleh tim pelaksana.

c. Adanya peningkatan keterampilan tangan peserta pelatihan dalam penggunaan bahan dari stik es krim dalam kategori baik.

d. Program pelatihan kerajinan tangan mampu memberikan penyegaran kepada ibu-ibu dalam menghasilkan bentuk kerajinan tangan yang baru.

\section{Pembahasan Hasil Pelaksanaan Kegiatan}

Berdasarkan hasil kegiatan yang telah dipaparkan pada hasil, bahwa kegiatan pengabdian ini mendapat respon yang positif dari ibu-ibu di RW.12 Kelurahan sagulung kota, dimana para peserta antusias mengikuti kegiatan, para ibu-ibu mengikuti dengan penuh semangat sehingga ketika mereka disuruh untuk mencoba membuat sendiri sebagai latihan yang diberikan para ibu-ibu bisa menyelesaikannya dengan baik dan juga mereka dengan senang hati membantu dalam proses awal sampai akhir.

Disisi lain masih ditemukan beberapa kendala dalam pelaksanaan, misalnya menentukan waktu, karena pelatihan ini dijadwalkan hari minggu kebetulan berbarengan dengan perayaan 17 Agustus dan kegiatan-kegiatan lain yang diselenggarakan pada minggu.

\section{KESIMPULAN}

Berdasarkan uraian pada hasil dan pembahasan di atas, maka dapat disimpulkan sebagai berikut:

1. Pelaksanaan kegiatan pelatihan kerajinan tangan menggunakan bahan dari stik es krim berjalan dengan baik.

2. Tanggapan mitra terhadap pelaksanaan kegiatan pelatihan cukup baik. Hal ini dapat dilihat dari indikator kehadiran ibu-ibu, dan selama kegiatan berlangsung mereka sangat antusias mengikuti kegiatan dari awal sampai akhir kegitan.

\section{REFERENSI}


(http://id.wikipedia.org/wiki/kerajinan).

(http://id. Wikipedia.org/wiki/kerajinan)

Ketut, Sudita, 2016. Pemanfaatan Barang Bekas Sebagai Bahan Pembuatan Barong Mini Dalam Pembelajaran Seni Kerajinan Tangan, Bali, Udayana

Yulia., Tesa 2017, Melakukan Daur Ulang Kertas Bekas Dan Dimanfaatkan Dalam Kehidupan Sehari-Hari, Tanjung Pati : Teknologi Pertanian Politekhnik Negeri Payakumbuh 